\title{
PRÁTICAS ESPACIAIS, COTIDIANO E ESPAÇO PÚBLICO:O CONSUMO COMO EIXO DA ANÁLISE DO CALÇADÃO DE PRESIDENTE PRUDENTE-SP'
}

\author{
PRACTICAS ESPACIALES, COTIDIANO E ESPACIO PÚBLICO: EL \\ CONSUMO COMO EIXO DE ANALISIS DEL CALÇADÃO (PASEO) DE \\ PRESIDENTE PRUDENTE-SP
}

\author{
SPATIAL PRACTICES, EVERYDAY AND PUBLIC \\ SPACE:CONSUMPTION AS THE AXIS FOR THE ANALYSIS OF THE \\ PUBLIC MALL IN PRESIDENTE PRUDENTE-SP
}

\section{Eda Maria Góes}

Doutorado em História pela Unesp - campus de Assis. Professora do Departamento de Geografia da Unesp, Membro do GAsPERR (Grupo de Pesquisa Produção do Espaço e Redefinições Regionais) e Subcoordenadora do Projeto Temático "Lógicas econômicas e práticas espaciais contemporâneas: cidades médias e consumo". Campus de Presidente Prudente. Universidade Estadual Paulista - UNESP. Rua Roberto Simonsen, 305, Centro Educacional - Presidente Prudente - SP, CEP. 19.060-900.

e.mail:emg071963@gmail.com

\section{Maria Encarnação Beltrão Sposito}

Doutorado em Geografia pela Universidade de São Paulo. Professora do Departamento de Geografia da Unesp, Membro do GAsPERR (Grupo de Pesquisa Produção do Espaço e Redefinições Regionais) e Coordenadora do Projeto Temático "Lógicas econômicas e práticas espaciais contemporâneas: cidades médias e consumo". Campus de Presidente Prudente. Universidade Estadual Paulista - UNESP. Rua Roberto Simonsen, 305, Centro Educacional - Presidente Prudente - SP, CEP. 19.060-900. e.mail:beltrao@fct.unesp.br

\section{RESUMO}

A “Geografia da vida cotidiana” possibilita a identificação dos sentidos do espaço e do outro que o frequenta, apropriando-se dele, e, portanto, produzindo-o, assim nos propomos a caracterizar as relações que se estabelecem nos calçadões de cidades médias, como Presidente Prudente (SP), norteadas pelo comércio e pela presença do espaço público. Outros sujeitos, além dos agentes econômicos e do poder público municipal emergem e são valorizados em suas práticas espaciais que podem ser tanto banais, porque cotidianamente reiteradas e, em geral, mediadas pelo consumo, como fugazes e imprevistas. Ambas são significativas, implicando em encontros que não são possíveis nos shopping centers ou nos espaços residenciais fechados, que cada vez mais predominam nessa cidade.

Palavras-chave: consumo; espaço público; práticas espaciais; calçadão; Presidente Prudente - SP.

A análise apresentada neste artigo é resultado da pesquisa "Lógicas econômicas e práticas espaciais contemporâneas: cidades médias e consumo", financiada pela Fundação de Amparo à Pesquisa no Estado de São Paulo (FAPESP) e coordenada pelas autoras. 


\section{RESUMEN}

La "Geografía de la vida cotidiana" posibilita la identificación de los sentidos del espacio y del otro que lo frecuenta, aproximándose a él y, por tanto, produciéndolo, por lo que proponemos caracterizar las relaciones que se establecen en los calçadões (paseos) de las ciudades intermedias, como Presidente Prudente (SP), dirigidos por el comercio y por la presencia del espacio público. Otros sujetos surgen y son valorizados, además de los agentes económicos y del poder público municipal, por sus prácticas espaciales que pueden ser tanto banales, porque son cotidianamente reiteradas y, en general, mediadas por el consumo, como son fugaces e imprevistas. Ambas son significativas, implicando encuentros que no son posibles en los shopping centers o en los espacios residenciales cerrados, que cada vez más predominan en estas ciudades.

Palabras clave: consumo; espacio público; practicasespaciales; calçadão; Presidente Prudente-SP

\section{ABSTRACT}

The "geography of everyday life" makes it possible to identify the purports of space, as well as of the other who frequents such space, making it his or her own, and thus, producing such space. The present article aims at a characterization of the relations established in pedestrian malls of medium sized cities like PresidentePrudente (SP, Brazil), guided by commerce and the presence of public space. Other actors emerge and are valued in their spatial practices, for they may be either banal (because constantly reiterated and generally measured by consumption), or fleeting and unpredicted. Both of these practices are relevant, as they imply in meetings that are not possible in shopping malls or closed residential spaces - which have grown to become predominant in this city.

Key words: consumption; public space; spatial practices; pedestrian mall; PresidentePrudente - SP - Brazil.

Neste texto,propomo-nos a analisar o caso docalçadão de Presidente Prudente, Estado de São Paulo, Brasil, com base em pressupostos, apoiados no reconhecimento da importância: 1. do binômio centro - centralidade, decorrente da disponibilidade de meios de transporte, que garantem acessibilidade, da presença dos serviços, do comércio e da sociabilidade que permeiam a relação de compra e venda no varejo; 2 . do consumo, como prática espacial predominante nessa área,o qual mudou de intensidade e conteúdo, bem como de status, conformando o mundo e se associando à tendência de individualização da experiência e aos processos de diferenciação (Bourdin, 2005); 3. da significativa presença dos espaços públicos neste eixo comercial do centro principal da cidade, ainda que seu conteúdo igualmente venha se alterando ou, em outros termos, venha sendo subvertido. 
Em que pese o caráter singular da via comercial, que tomamos como referência empírica para a análise desenvolvida, consideramos que a reflexão apresentada oferece elementos para compreender o que é particular a espaços urbanos menos complexos que as metrópoles e ao que é universal no período atual, no tocante às formas de produção e, portanto, também de apropriação do espaço urbano.

\section{ESPAÇO, TEMPO E CONSUMO: INTRODUZINDO 0 DEBATE}

O espaço-tempo do consumo converte-se, progressivamente, em espaço-tempo dos indivíduos, segundo Lipovetsky e Serroy (2010,p.63-64), os quais, ao abordar o hiperconsumo, caracterizam a esfera comercial como "onipresente, tentacular e ilimitada". Mesmo considerando-se esta tendência, é preciso analisar as dinâmicas, ações e práticas para compreender como o processo geral pode se consubstanciar em múltiplas formas de combinação entre espaço, tempo e consumo, tanto quanto podem ser lidas a partir de diferentes enfoques analíticos.

Tendo em vista este ponto de partida, a perspectiva da análise é a da "Geografia da vida cotidiana”, que estuda a relação espaço-sociedade das situações de interação, referidas às pessoas situadas espaço-temporalmente num contexto intersubjetivo a partir do qual dão sentido ao espaço e ao outro (Lindón, 2006, p.357), sendo, portanto,imprescindívela apreensão das práticas espaciais daqueles que frequentam o calçadão de Presidente Prudente e a compreensão da produção desses espaços urbanos, valorizando-se sempre suas múltiplas temporalidades

Além de dinâmicas, as práticas espaciais, inclusive as de consumo, comportam relações contraditórias entre reprodução e inovação, entre repetição e criação, entre o esperado e o inusitado, pares estes em frequente tensão.A articulação intrínseca entre formas de reprodução econômica e social, de um lado, e práticas, de outro, já foi destacado por Alonso (2006, p. 31) que compreende o consumo como reprodução da estrutura social, mas também como estratégia de ação, entendida por ele, como as "práticas reais dos sujeitos".

Assim, tais relações só podem ser identificadas quando se valorizao papel de cada citadino como sujeito no processo de produção do espaço urbano, ainda que seus limites e possibilidades não sejam os mesmos dos agentes produtores do espaço urbano, como as empresas que atuam no calçadão de Presidente Prudente; tampouco sejam os dopoder público,responsável pela transformação de cada uma dessas áreas em exclusivas dos pedestres e pela implementação de políticas de requalificação, por exemplo,cujainfluêncianas formas de uso social e econômico deste espaço é reconhecível. 
Envolvendo questões aparentemente banais, as práticas espaciais expressam dimensões da vida social, micropolíticas e culturais, assim, sua inter-relação com a subjetividade é complexa: sentidos, significados e imagens sobre os espaços se constroem e tomam forma, no desenvolvimento das práticas e, ao mesmo tempo, uma vez construídos, condicionam as práticas futuras. Essas, por sua vez, podem levar a reconstrução dos sentidos (Lindón, 2006, p.370), como ocorre com o consumo, transformado em“campo" fundamental para instaurar e comunicar diferenças (Bourdieu, 2008). As relações entre práticas espaciais e subjetividade são ainda mais importantesno período atual, o qual Alonso (2006, p. 53) caracterizou como aquele da "ordem fordista ampliada", pois tal ordem constitui-se em "organizador genérico de tempos e de estilos de vida".

Recentemente no Brasil, a relativa democratização produzida ao massificar-se o acesso aos produtos (desde roupas e sapatos a residências, passando pelos eletroeletrônicos) estimula a produção de espaços exclusivos (ou assim representados),inclusive para resolver as urgências da vida cotidiana (agências e serviços bancários especiais² ${ }^{2}$, condomínios exclusivos, shopping centers...). Além de envolver o deslocamento do cotidiano e do econômico para o simbólico, da produção para o consumo, com todos os encobrimentos decorrentes, na conformação desse campo estruturado a partir do consumo, os espaços urbanos ganham cada vez mais importância, tanto quanto as múltiplas formas de uso do tempo que ensejam e expressam.

As relações intrínsecas entre a cidade e seus espaços públicos têm sido amplamente reconhecidas, ao mesmo tempo em que as particularidades da moderna concepção de espaço público, às promessas nela implicadas e sua subversão, que está em curso, têm sido objeto de intenso debate. Atento à historicidade do conceito, Delgado (2011) identifica sua gênese e importância nas retóricas político-urbanísticas e nas suas respectivas agendas, demonstrando, a partir de uma genealogia do emprego da própria expressão, que nem nas obras de Henri Lefebvre (1974), nem de Jane Jacobs (1961), por exemplo, ela está presente. Até os anos 1980, empregava-se "espaço urbano", “espaço social”, “espaço coletivo", enquanto interpretações no campo da filosofia política eram produzidas por Arendt (1958), numa linha, e por Habermas (1962), em outra, que têmem comum sua interpretação como categoria política, mas diferenciam-se porque a primeira baseia-se num "modelo grego" de espaço público, enquanto o segundo adota um "modelo burguês".

Para a análise proposta nesse texto, tal debate importa uma vez que nenhuma das concepções mencionadas acima fornece parâmetros para a compreensão dos espaços pú-

\footnotetext{
Referimo-nos à tendência dos últimos 10 anos de abertura de agências bancárias para correntistas de maior capacidade de investimento e compra de serviços bancários, como as unidades 'Estilo' do Banco do Brasil, 'Personnalité do Banco Itaú, 'Prime’ do Bradesco etc.
} 
blicos presentes nas cidades atuais, como Presidente Prudente. Isso ocorre porque predomina uma sobreposição de interpretações que até então eram independentes: a do espaço público como conjunto de lugares de livre acesso e a do espaço público como âmbito no qual se desenvolve uma determinada forma de vínculo social e de relação com o poder, ou seja, no qual se engendram relações políticas (Delgado, 2011).

Muitas vezes há pouca distinção entre espaço público e vida pública, o que dificulta a construção de uma concepção mais adequada de espaço público no período atual. Gomes (2002, p. 159-160) chama atenção sobre a fragilidade de se conceber este espaço, apenas, como aquele que não é privado ou como área juridicamente delimitada ou, ainda, como o espaço de livre acesso de todos.

Acrescentamos, ainda, que é fundamental reconhecer sempre, a articulação entre espaço público e esfera pública, mas não confundi-los no plano analítico, na direção de reduzir, estritamente, um ao outro. Nem sempre a vida pública ou, em outros termos a realização da esfera pública da vida social e política, é vivenciada ou se realiza, somente, em espaços públicos, uma vez que ela pode se efetivar em ambientes privados, ainda que de acesso e uso coletivo, como os shopping centers. Entretanto, dadascertas características de espaços como estes, com destaque para o direito legal e social de controle privado sobre eles, a realização da esfera pública não é efetiva ou pode ocorrer de modo segmentado e, por tal, incompleto. Do mesmo modo, em espaços públicos, em que as condições em tese para a realização da esfera pública são plenas, ela também pode ser interceptada por práticas de controle, seja do poder público, seja da iniciativa privada, que inviabilizam a sua plena consecução ${ }^{3}$.

Estas múltiplas possibilidades mostram a intensa articulação entre o público e o privado, mais que isso uma efetiva interpenetração entre tais dimensões que ampliam o desafio que se apresenta para análise de tais dimensões, suas distinções e contradições.

A identificação da sobreposição de interpretações, de um lado, e de fragilidades conceituais e analíticas, de outro,favorece a compreensão das constantes denúncias em relação a uma subversão generalizada e inescapável do espaço público moderno, feita por especialistas de diferentes áreas. Elas são feitas seja com base em análises estruturais sobre os processos que estão em curso nas cidades, seja com base em pesquisas empíricas, nas quais predominam as dimensões materiais e imateriais dos espaços públicos analisados, com base nas quais os desígnios do capital são sempre comprovados. Muitas vezes não possibilitam compreendê-lo, nos termos propostos por Gomes (2002, p.160-161), como

3 De algum modo, isto se combina com a caracterização que Souza (2008, p.80) faz de espaços coletivos, como aqueles podem ser compreendidos como meramente de uso comum, mas desprovidos das condições que nos possibilitariam vê-los como espaço público. 
o espaço que tem relação direta com a vida pública, o que significa a comunicação entre diferentes indivíduos possibilitada pela intersubjetividade, ou seja, para que um não seja reduzido ao outro (ou confundido com ele), estabelece-se no espaço público uma dada natureza de interlocução que precisaria para ser respeitada, nos dias atuais, da refundação deste espaço como espaço político.

Por não levar em conta a necessária articulação, mas também distinção entre espaço público e vida pública, bem como o caráter dinâmico das práticas espaciais e a complexidade das suas relações com a subjetividade, muitas leituras impossibilitam a reconstrução constante (e necessária) dos sentidos com base nos quais os espaços são produzidos, uma vez que "o espaço, tanto público quanto privado, é antes de tudo um lugar praticado que aparece - se constitui na ação" (Cortês, 2008, p.72).

O significado, o alcance e a importância das práticas espaciais, ainda que fugazes e imprevistas, que implicam na possibilidade ou necessidade de se visualizar os outros, diferentes, não são percebidos se não se contextualizam os espaços públicos pesquisados em realidades urbanas concretas, como a referência que selecionamos neste artigo, atinente à cidade de Presidente Prudente, no que se refere à predominância de muros e outros mecanismos de segurança e de controle social que não apenas privatizam, como impedem a circulação, o acesso, a presença e até a visibilidade dos outros, que são discriminados, produzindo o que Caldeira (2000) denominou adequadamente de "cidade de muros". Em outros termos, frente a tantas barreiras e limites, tão ostensivos como visíveis e não permeáveis, produzidos no âmbito de um processo que vai além da segregação socioespacial, como não valorizar acopresença, a visibilidade, a proximidade e a inovação que possibilitam os espaços públicos?Como não avaliar tais fatos em contraponto e combinação com a ideia de separação e segmentação, individualismo e indiferença responsáveis pelas condições objetivas e subjetivas, materiais e imateriais de redefinição contemporânea do par espaço privado - espaço público (Sposito e Góes, 2013, p. 133)? Como não levar em conta os processos objetivos de privatização sustentados pela valorização de "espaços privados, mas de acesso e uso coletivo", como os shopping centers, representados (e vendidos) como superiores à cidade, justamente porque capazes de neutralizar imprevisibilidades (Sarlo, 2009)? Ou, ainda, como não considerar os "espaços públicos de uso coletivo privado" (Sposito e Góes, 2013, p.157) como os de loteamentos juridicamente não condominiais, cujos espaços públicos estão dentro dos muros, com aquiescência do poder público?

Frente às relações dialéticas entre a homogeneidade, decorrente da relativa democratização do consumo,por um lado, e, por outro, da renovação e ampliação das estratégias de distinção,e das denúncias recorrentes de que o consumo tornou-se predominante 
também nos espaços públicos, as práticas espaciais possibilitam a identificação dedisputas, sobretudo simbólicas, sobre esses espaços. Nossa hipótese é que tais disputas conferem uma dimensão políticaaos espaços públicos, o que se evidencia quando as comparamos àquelas presentes nos "espaços privados de acesso e uso coletivo", conforme nos propomos a demonstrar nesse artigo produzido no âmbito do projeto temático já enunciado na nota 1 deste texto,a partir de um conjunto variado de procedimentos metodológicos realizados. No caso desse artigo,sobre Presidente Prudente ${ }^{4}$, apoiamo-nos: em entrevistas com citadinos residentes em diferentes áreas da cidade, na aplicação de enquetes no centro ${ }^{5}$, em entrevistas com "agentes bem informados", em observações de campo feitas no calçadão, em diferentes dias e horários, além de consulta à bibliografia.

Como se busca apreender processos, movimentos e dinâmicas, com suas ressignificações, passamos ao reconhecimento da importância das relações entre espaço e tempo, através da história da cidade e da origem do seu calçadão.

\section{PRESIDENTE PRUDENTE: HISTÓRIA DA CIDADE, ORIGEM E PRIMEIRA ANÁLISE DO CALÇADÃO}

A despeito da condição periférica do Brasil no capitalismo, no início do século XX, é assim, como cidade capitalista, pautada em interesses fundiários de dois grandes proprietários de terras, que também eram dois coronéis, Goulart e Marcondes, que Presidente Prudente nasceu em 1917, em pleno Oeste Paulista, região então denominada Sertões do Paranapanema. Como outras surgidas a partir da expansão da rede ferroviária, como nós da rede de transporte e, ao mesmo tempo, constituindo-se como nós da rede urbana, estavam voltadas ao abastecimento daqueles que chegavam para trabalhar no café. Sua primeira centralidade se referenciava na estação de trem, na escala da cidade, e nas relações entre o urbano e o rural, na escala da rede urbana regional, que se constituía pelas articulações entre cidade e campo e entre as cidades nascentes, cujo sentido da existência estava fortemente associado à produção agrícola.

Na escala da cidade, foi a combinação entre irregularidade e regularidade presente na Vila Goulart que atraiu os interesses de proprietários de terras e comerciantes, principais produtores do espaço urbano naquele contexto inicial, o que significou ausência de calçamento, água encanada e esgoto, por exemplo.Nos anos 1930, esse quadro começou a mudar. A promulgação da Lei Orgânica dos Municípios, em 1935, teria sido importante fator de mudança, quando "o centro como 'obra', com marcos de administrações municipais que viessem a caracterizá-lo... começa a surgir” (Whitacker, 1997, p.137): primeiros

\footnotetext{
4 No projeto temático, são seis as cidades pesquisadas: Londrina, Marília, Presidente Prudente, Ribeirão Preto, São Carlos e São José do Rio Preto.

5 Enquetes aplicadas em 11/09/2013, 18/09/2013 e 05/10/2013.
} 
serviços de sarjetas e plano de calçamento, primeiro pontilhão sobre os trilhos da Estrada de Ferro Sorocabana, unindo os dois núcleos até então ligados apenas por uma passagem em nível e a Praça 5 de julho (atual Praça 9 de julho). De espaço improvisado à obra avançada para a época, a praça assumiu papel simbólico na constituição da centralidade de Presidente Prudente e que vem sendo tensionado nas últimas décadas.

Figura 1 -Presidente Prudente. Situação geográficado município e de seu calçadão no espaço urbano

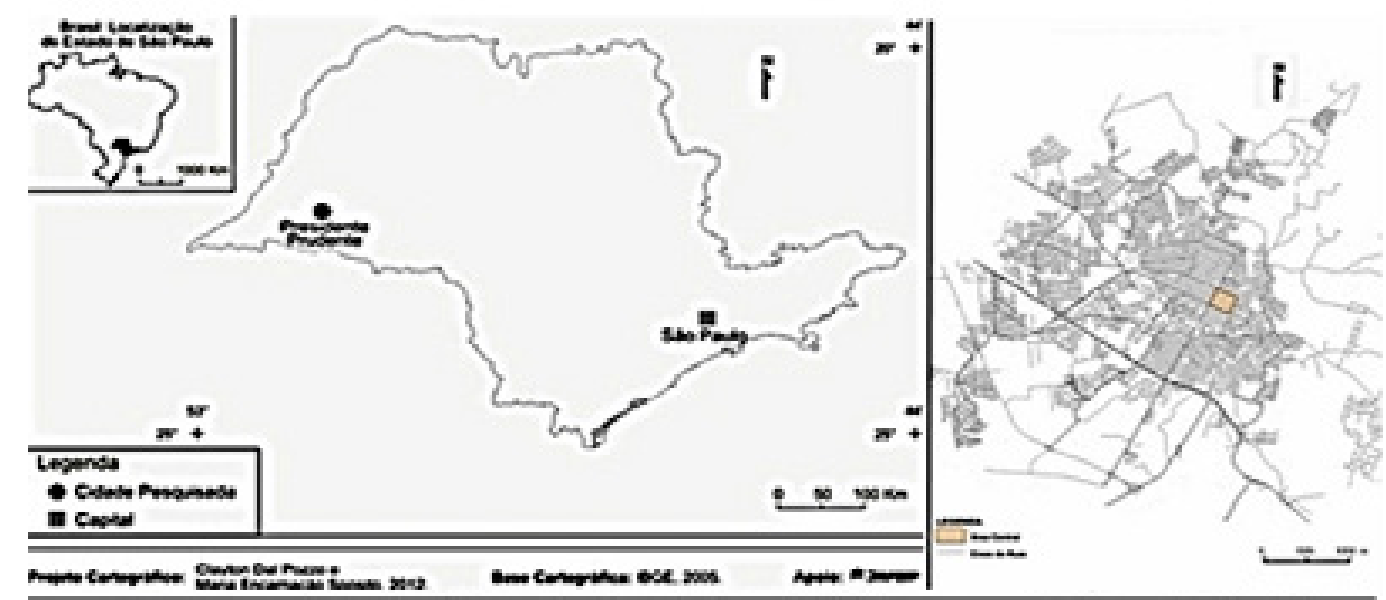

Presidente Prudente: Quadrilátero central e Calçadão

(1)

ơ

U

응

ह

$<\sum^{2}$

0

$\frac{0}{\frac{1}{2}}$

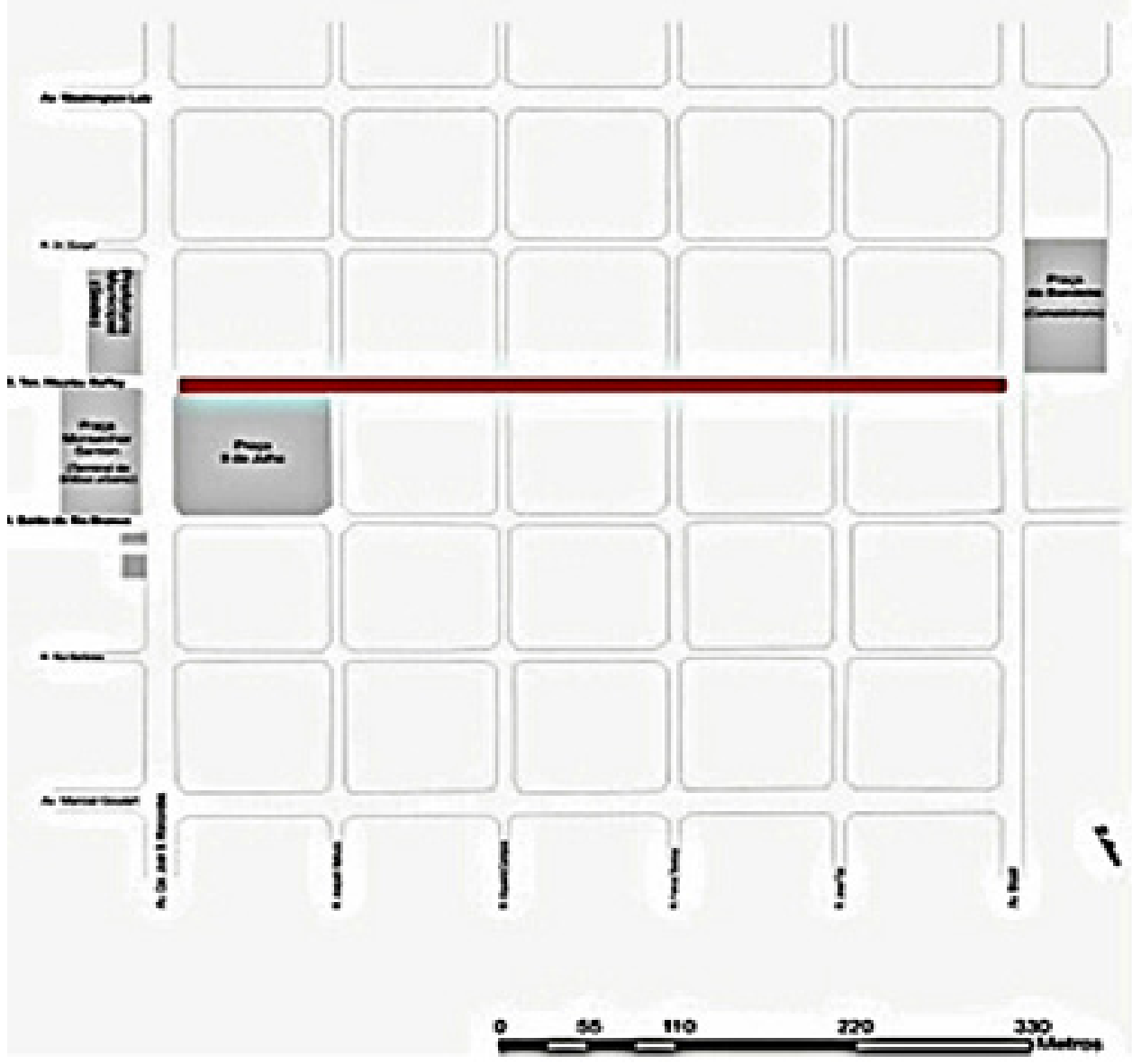

a 
Em Presidente Prudente, o chamadoquadrilátero central que tem sua origem no traçado retilíneo das vias do primeiro parcelamento urbano da cidade, a Vila Goulart, passou por transformações: na nomenclatura e uso de ruas e avenidas, cada vez mais voltadas aos automóveis; nas antigas habitações, sobretudo dos casarões da elite prudentina, convertidos em estabelecimentos comerciais e de serviços ou substituídos por novos edifícios mais adequados a tais funções. As mudanças experimentadas pela cidade e por seu centro acompanhavam e reproduziam tendência, já então predominante nas metrópoles brasileiras, de especialização funcional e de distinção socioespacial.

Nesse processo, a materialização das múltiplas relações estabelecidas entre o velho e o novo, cuja dinâmica acelerada e, por vezes, particularmente destrutiva em relação ao velho, representado frequentemente de forma negativa, como entrave e atraso, ganha sentido no âmbito de uma história urbana pautada pela sociedade capitalista e por suas lógicas. As permanências só podem ser identificadas quando o olhar do pesquisador vai além do olhar dos citadinos que cotidianamente frequentam o centro, observando, por exemplo, o que está acima do campo corriqueiro da visão de um transeunte, como a parte superior das fachadas comerciais.

Levando em conta que cada fachada é uma totalidade, uma unidade que se abre para outras, mas que, ao mesmo tempo, participa diretamente da composição do todo (Kohsldorf, 1996), ainda que a intenção principal seja chamar a atenção do consumidor a qualquer custo, conclui-seque, no calçadão, predomina uma arquitetura comercial de transição (Vargas, 2001). São edificações resultantes de sucessivas adaptações de antigas residências, ou mesmo de outros estabelecimentos comerciais, que, muitas vezes, tiveram como objetivo alterar apenas a fachada do piso térreo, como mostraremos adiante por meio de uma das imagens que compõem a Figura 5. No piso superior, permanecem evidências, mais ou menos visíveis (por vezes mal disfarçadas por letreiros, luminosos e envidraçamentos), tanto de funções, como de estilos arquitetônicos anteriores, que também podem ser expressões, ainda que indiciárias, de um processo real de degradação, que tem sido elaborado no nível dos discursos e dos imaginários urbanos (Canclini, 2007) dos prudentinos, desde os anos 1970.

Nesse processo eivado por tensões, o quadrilátero central delimitado pelas atuais avenidas Coronel Marcondes, Manoel Goulart, Washington Luís e Brasil, consolidou-se como espaço central, caracterizado pelo comércio, serviços e administração pública, mas também pela sociabilidade e o lazer, representados, sobretudo, pelas Praças 9 de julho e Monsenhor Sarrion, por causa do calda de cana e da espera dos ônibus, bem como pela presença da Catedral de São Sebastião. 
Em dezembro de 1979, foi inaugurado o calçadão. Duas ordens de interesses convergiram na sua criação. Enquanto expressão da atuação do poder público municipal na defesa dos interesses dos capitais já instalados na área central, o projeto pretendia reforçar sua centralidade assentada, sobretudo, nas atividades comerciais varejistas, reagindo a uma crise que já pautava os discursos predominantes sobre esse espaço. Como um modismo, evidenciado quando se leva em conta as características do projeto baseado em experiências anteriores, de cidades paulistas e paranaenses, ou seja, que desconsiderava especificidades e demandas locais, coincidindo com a implantação de edificações em concreto e vidro que, em seu conjunto, expressam tendência à padronização (Hirao, 1990).

Mesmo assim, seja pelas resistências mobilizadas, sobretudo pela Associação Comercial e Industrial de Presidente Prudente (ACIPP), seja pelas intermitências da administração pública municipal, embora o projeto fosse direcionado a duas ruas paralelas - Tenente Nicolau Maffei e Barão do Rio Branco -, apenas a primeira foi transformada em calçadão(Figura 1), o que passou a ser valorizado pelos citadinos em geral e pelos comerciantes, cujos negócios nela se situavam. A preocupação com a disponibilidade de vagas para estacionamento é constante desde então e foi mencionada por todos os citadinos que entrevistamos durante a pesquisa, inclusive os aposentados, ou seja, aqueles que não estão mais diretamente influenciados pelos ritmos do trabalho; todosdeclararam não frequentar essa área da cidade em função das dificuldades para estacionar.

Quanto aos interesses dos capitais, a rua de pedestres passou a exercer e exerce atração às empresas do setor financeiro, em especial, aos grandes bancos, lojas de departamentos, estabelecimentos comerciais tradicionais da cidade, voltados à população de maior poder aquisitivo, bem como principais escritórios de empresas públicas e privadas (Whitacker, 1997).Issonão alterou, mas reforçou a tendência de representação simbólica da área central como espaço de comércio varejista e de trabalho, cuja vitalidade era cotidianamente determinada pelo funcionamento dos estabelecimentos voltados a tais atividades. A observação cotidiana do calçadãoe o contato direto com os frequentadoresrevelaram outras possibilidades, além daquelas contidas no referido imaginário, conforme demonstramos no tópico seguinte desse artigo.

As relações entre espaço e tempo também são fundamentais para a compreensão da forma do calçadão. Além das resistências iniciais despertadas pela sua implantação, o calçadão é interrompido por quatro ruas nas quais a circulação de veículos motorizados é livre (Figura 1). Ainda que esforços tenham sido feitos para garantir a redução da velocidade dos veículose para priorizar a passagem dos pedestres, tais interrupções relativizam a exclusividade dos pedestres no calçadão, provocando descontinuidades e disputas entre pedestres e veículos nos quatro cruzamentos. 
Assim, a inauguração do calçadão, no final de 1979, remete a um contexto no qual o automóvel já havia assumido papel central nas cidades brasileiras. Em cidades surgidas no século XX, como é o caso de Presidente Prudente, em plena sociedade capitalista, a disposição para adaptação das práticas espaciais e das condições materiais necessárias à sua implementaçãoquase não encontraram resistências. As respostas dos citadinos entrevistados confirmam a poderosa representação simbólica da “cidade do automóvel”, contraposta à "cidade para pessoas" (Ghel, 2013), na produção cotidiana dos espaços urbanos brasileiros, que limita as possibilidades de valorização de outros aspectos presentes no calçadão, especialmente depois das últimas reformas. Ao mesmo tempo, naturalizam-se justificativas para a evitação dos espaços públicos, cada vez mais associados à imprevisibilidade representada como negativa.

Representados (e vendidos) como capazes de neutralizar imprevisibilidades, o Shopping Americanas e o Prudenshopping foram muito bem vindos em Presidente Prudente, inclusive disputados. Mesmo que conformidade não seja sinônimo de homogeneização e que seja estratégico o compartilhamento de códigos e signos que diferenciam globalmente um grupo dosdemais (Baudrillard, 1991, p.112), a capacidade de difusão desses códigos e signos para os outros grupostambém é fundamental, sobretudo para garantir à elite seu papel. Assimcompreende-se porque osshopping centers estão associados à representação simbólica da cidade moderna, muito almejada e refratária às críticas.

Os processos de implantação de cada um dos dois shopping centers são expressivos da heterogeneidade das relações que podem se estabelecer entre as administrações municipais e os grandes capitais, assim como de seus desdobramentos.Pioneiro na associação entre comércio e lazer, o Shopping Center Americanas ${ }^{6}$ foi implantado em 1986, num bairro já densamente ocupado, sobretudo por residências e consultórios médicos, muito próximo da Santa Casa e do terminal de transportes rodoviários, num terreno bem localizado, onde anteriormente estavam as instalações e o campo de futebol do Esporte Clube Corinthians de Presidente Prudente. Essa localização possibilitou o estabelecimento de relações diversas com o centro, mas não chegou a alterar o papel por ele desempenhado, inclusive em relação às cidades do entorno.

\footnotetext{
6 O Shopping Center Americanas passou a se chamar Parque Shopping Prudente em 2007, depois de ser adquirido pela General Shopping Brasil. Em 21 de março de 2016, este grupo informou à Comissão de Valores Mobiliários (MVM), que vendeu o total da sua participação neste empreendimento (fonte: http://economia.uol.com.br/noticias/valor-online/2016/03/21/general-shopping-se-desfaz-de-participacao-no-parque-shopping-prudente.htm) enquanto, no início de abril já se divulgava que o grupo paranaense Muffato, o sexto no país no ramos de supermercados, foi o adquirente (fonte: http://fusoesaquisicoes. blogspot.com.br/2016/04/grupo-paranaense-muffato-avanca-em.html), o que foi confirmado pela imprensa de Presidente Prudente, em 11 de maio de 2016, pelo Jorna o Imparcial (fonte: http://fusoesaquisicoes.blogspot.com.br/2016/04/grupo-paranaense-muffato-avanca-em.html).
} 
Em 1990, foi inaugurado o Prudenshopping, exemplo radical de associação entre interesses da administração pública municipal e interesses privados.Foi a Prefeitura Municipal de Presidente Prudente que, proprietária do terreno, iniciou a construção do então denominado Shopping Center Aicás,nos anos 1980 (Sposito, 2001), reproduzindo a lógica do mercado imobiliário. Novo elemento introduziu-se ainda no decorrer da sua construção, quando se associou ao poder público municipal a Construtora Júlio Bogoricin, assim como o Grupo J. Alves Veríssimo. Mas antes da inauguração, a Encalso adquiriu as ações dessa construtora e, meses depois da inauguração (11/1990), as ações do município, sendo até hoje a proprietária do Prudenshopping(Sposito, 2001), além de ser responsável também por espaços residenciais fechados de médio e alto padrão em Presidente Prudente e em muitas outras cidades brasileiras ${ }^{7}$.

Localizado num cruzamento das Avenidas Manoel Goulart e Washington Luís, num ponto, e no cruzamento das Avenidas Manoel Goulart e 14 de Setembro, no outro, o Prudenshopping beneficiou-se não apenas da disponibilidade das vias de acesso, como do processo de valorização dessa área, após a criação do Parque do Povo, maior espaço público de lazer da cidade. Nota-se a localização estratégica deste estabelecimento, inclusive no que se refere à ligação com a Rodovia Raposo Tavares e, portanto, ao acesso, via automóvel, dos moradores das cidades do entorno. Tal combinação explica o impacto que exerce sobre o calçadão de Presidente Prudente, como novo subcentro que, no entanto, não chega a se igualar com a intensidade dos fluxos que para lá convergem, e que não pretende fazê-lo, em função do desejo de seletividade que caracteriza as políticas implementadas pelos shopping centerse as práticas espaciais que lá predominam, a despeito dos limites e dilemas que sempre comportou.

A oferta de estacionamentos pelo Prudenshopping, valorizando os deslocamentos por automóvel, signo estratégico na representação simbólica da cidade moderna, acaba por ser indicativa das contradições dos discursos dos citadinos entrevistados, inclusive do prefeito $^{8}$ e de um agente imobiliário ${ }^{9}$, quando se leva em conta seu funcionamento cotidiano. Em função da sua própria capacidade crescente de atração, tem sido cada vez mais frequentes, não apenas as filas para se conseguir vagas, como o fato de que se pague

\footnotetext{
7 "Fundado em 1964, o Grupo EncalsoDamha é um conglomerado empresarial que atua nas áreas de Engenharia Civil, Agronegócios, Concessão de Rodovias, Gestão de Shopping Center, Concessão de Energia e Empreendimentos Imobiliários”. No que concerne a este último ramo de atividade, já foram vendidos lotes em 46 espaços residenciais fechados e estão a venda terrenos em outros 12 espaços deste tipo, operando o grupo em nove estados da federação e no distrito federal." Fonte: http:// www.damha.com.br/institucional/grupo-encalso-damha/

8 Entrevista realizada por Maria Encarnação B. Sposito, Márcio J. Catelan e Nécio Turra Neto em 22/03/2013, na qual o Prefeito Municipal Milton Carlos de Mello “Tupã” referiu-se ao "caos que é o centro, [para] estacionar o carro...”.

9 Entrevista realizada por Maria Encarnação B. Sposito e Eliseu S. Sposito com Lucas Krasucki, da Luka Imobiliária, em 28/10/2014, na qual ele afirma: "o centro da cidade é estrangulado, não tem estacionamento, é horrível estacionar...".
} 
para estacionar e, mesmo assim, seja necessário caminhar até 300 metros desde o ponto mais distante até uma das portas do Prudenshopping, como não é raro nessa cidade, sob sol intenso. Contraditoriamente, é apenas em relação ao calçadão, cujas transversais e paralelas foram transformadas em estacionamentos (Zona Azul) e em cujas proximidades há estacionamentos privados, que a falta de estacionamento é considerado impedimento para frequência doscitadinos de classe média que entrevistamos ${ }^{10}$.

Desse modo, a assertiva de Canclini (2013, p.37) de que "as sociedades modernas necessitam ao mesmo tempo da divulgação - ampliar o mercado e o consumo dos bens para aumentar a margem de lucro e da distinção -, que para enfrentar os efeitos massificadores da divulgação, recria os signos que diferenciam os setores hegemônicos", ganha materialidade quando é espacializada, e assim identificamos sua especificidade nas cidades médias, nas quais as classes médias exercem papel estratégico, seja como consumidoras, seja como sujeitos políticos.

\section{PRÁTICAS ESPACIAIS, CONSUMO E MUDANÇAS NO ESPAÇO PÚBLICO: O CASO DOCALÇADÃO DE PRESIDENTE PRUDENTE}

Retomando o pressuposto de que a vida cotidiana é o lugar do consumo, reconhecemos que, por um lado, ela se apresenta como banalidade e repetição e, por outro, é invadida pelos meios de comunicação de massa que a tornam um simulacro do mundo e de participação num mundo associado ao "prazer de comprar", do qual parcela significativa da população brasileira foi historicamente excluída até os anos 2000.Ao espacializare temporalizar tal assertiva numa realidade urbana concreta, como Presidente Prudente, constatamos que uma característica mantida, própria da cidade média ${ }^{11}$, foi a atração de consumidores da rede urbana próxima, exercida por sua área central, na qual o calçadão desempenha papel estruturante, conforme demonstram os gráficosda Figura 2:

\footnotetext{
${ }_{10}$ Em função das dificuldades de contatos, quase não foram feitas entrevistas com citadinos de elite em Presidente Prudente.
}

${ }^{11}$ O papel exercido na sua rede urbana é característica fundamental para a definição de cidade média (Sposito, 2007). 
Figura 2: Município de residência, distribuição por idadee motivação dos frequentadores do calçadão de Presidente Prudente. 2013

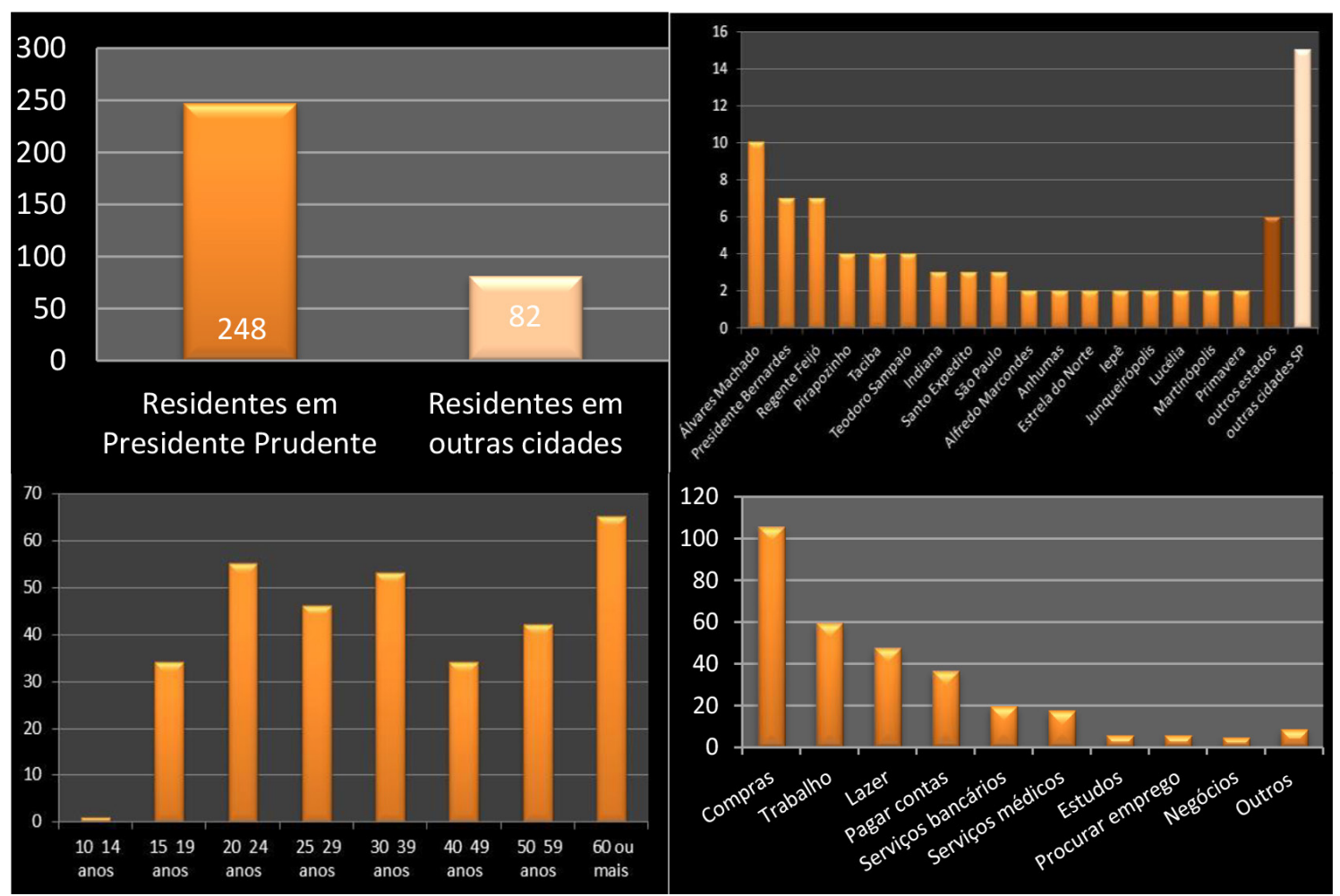

Fonte: Trabalho de campo, 2013

Na escala da cidade, também se constatam permanências, como a exclusão, sempre relativa e, infelizmente, naturalizada,que continua a ser reproduzida e se expressa pelo processo de fragmentação socioespacial que, indo além dos espaços de residência, atinge os espaços comerciais e de serviços, incluindo neles o lazer. Dinâmicas deste tipo, observadas no espaço urbano, não podem ser compreendidas sem articulações em múltiplas escalas geográficas. Assim, à tendência de homogeneização, estimulada por uma economia cada vez mais mundializada e uma sociedade progressivamente globalizada, está a de fragmentação social (e, por conseguinte, espacial). Esse processo é destacado por Alonso (2006, p.67) que entende que as próprias identidades sociais estão mais fragmentadas e se multiplicam, como decorrência mesmo do fato de consumir e dos efeitos sociais e culturais das práticas de consumo. Do mesmo modo, contrapõe-se a tal movimento de homogeneização, a constatação de que, segundo Bourdin (2005, p.84), o modelo de consumo atual contribui à individualização da experiência e à aceleração da diferenciação.

Por isso, as particularidades devem sempre ser observadas para que a afirmação das teses gerais ganhe conteúdo, a partir do vivido, e elas possam ser confirmadas ou refutadas. Houve, no caso brasileiro, mudanças, sobretudo no que se refere à ampliação do aces- 
so ao consumo, como já destacamos no início deste tópico. Mostrar as diferenças ou olhar o mesmo fenômeno - aumento do consumo - a partir de vários pontos de vista ou portas de entrada parece-nos importante.

Coerente com a perspectiva da "Geografia do cotidiano" de valorização dos citadinos como sujeitos ativos, nesse artigo, começamos porpriorizar os jovens citadinos frequentadores do calçadão de Presidente Prudente, cujas práticas espaciais são significativas, ainda que não sejam necessariamente predominantes. A Figura 2 atesta a presença desses jovens, a partir dos resultados da tabulação das enquetes.

Nas observações de campo, constamos que os jovens circulam pelo calçadão, por vezes rapidamente, indicando a influência do mundo do trabalho e de sua temporalidade; em outras situações, sós, em pequenos grupos, em duplas, partilhando o mesmo fone de ouvido, o que pode evidenciar tanto carência, como solidariedade, além da incorporação de novas práticas de consumo; em família, sobretudo, quando param para olhar vitrines. São visualmente semelhantes aos jovens que circulam pelos centros de qualquer cidade, guardadas as particularidades climáticas: calça jeans e camiseta, aparelho ortodôntico, brinco e boné, colocado sempre numa certa posição, além das tatuagens. Para esses jovens, o calçadãoé espaço para ver e ser visto, porque, para eles, tais distinções não fazem sentido e todos os espaços integram-se pelo consumo, transformados em campo (Bourdieu, 2008, p.211), no qual a economia política das práticas realiza a sintonia com imagens-símbolos de modernidade e urbanidade. Esta perspectiva não difere daquela caracterizada por Alonso (2006, p. 95), o qual caracterizando o final dos anos do século passado e tomando como referência a Europa, afirma que os jovens buscam integrar-se na sociedade de consumo, diferentemente da oposição que a ela faziam vinte anos antes.

De todo modo, é importante destacar algumas especificidades da nossa formação social e de nossas cidades. Entre os trabalhadores, há jovens distribuindo panfletos, anunciando produtos (com autofalante) na porta de lojas populares, como vendedores ambulantes, com vestido de mulher e peruca escandalosa, fazendo propaganda de "curso de beleza" e apostando assim no caráter inusitado de suas performances para chamar a atenção. Mas também há jovens entre os que dormem num banco da Praça 9 de julho e entre aqueles que catam material reciclável. Todos eles praticam o calçadão como espaço público, uma vez que cada uma das ações e práticas implica na e depende da abertura e acessibilidade que caracterizam este espaço.

Entre aqueles que andam pelo calçadão, muitoslevam capacetes pendurados no braço, indicando que também circulam de moto pelos outros espaços urbanos, o que é atestado pela presença expressiva desses veículos estacionados nas vias transversais (Figura 3). 


\section{Figura 3: Presidente Prudente. Movimento no calçadão e motocicletas na área central.2014}

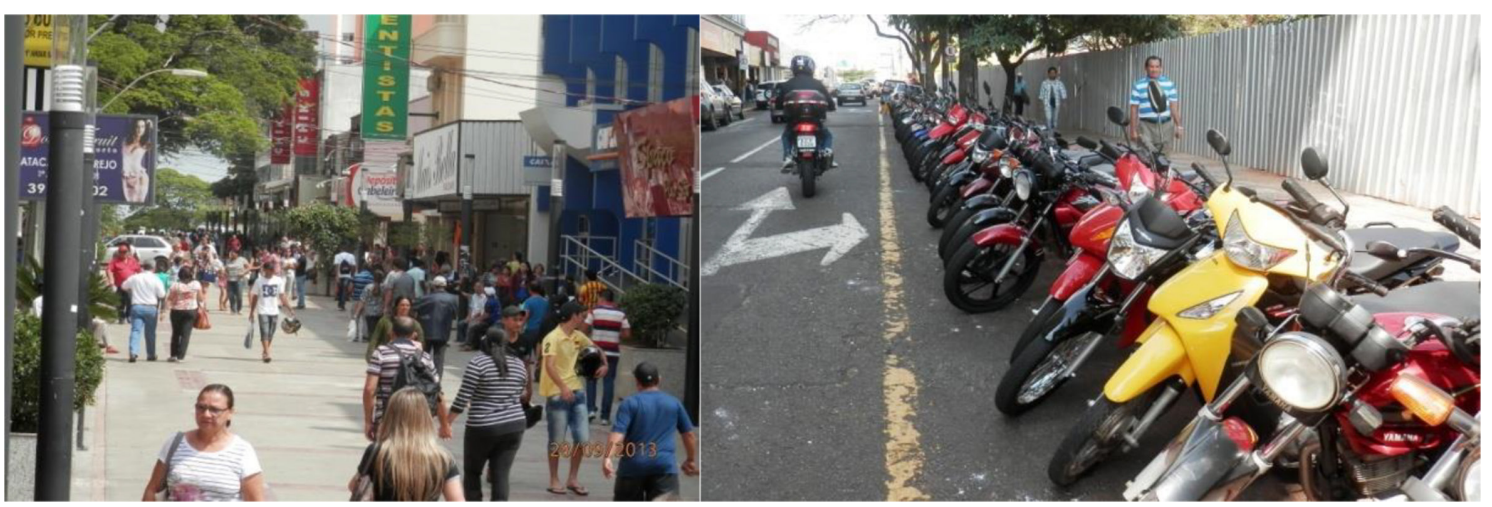

Fotosde Eda Góes, 2014.

No que se refere às manifestações artísticas, embora não sejam presenças constantes, observações cotidianas desse espaço revelam que são mais frequentes do que sua atual representação permite supor e também podem envolver os jovens. Dois exemplos, bem diversos são apresentados em seguida.

Primeiro exemplo: num espaço em que apenas esculturas alusivas a antigos prefeitos e outras autoridades públicas estão presentes nos espaços públicos contíguos ao calçadão, uma "estátua viva" foi presença discreta numa terça-feira (30/07/2014). Com referência à figura religiosa e materna, mas completamente pintada de prateado, a "estátua viva" estava imóvel em área movimentada do calçadão, na qual predominam agências bancárias. Inicialmente não chamava a atenção de ninguém, exceto de uma família sentada em banco próximo e de poucos frequentadores da área, que lançavam olhares de longe. Em seguida, três crianças da família que estava próxima conversam com a estátua, ela desce do pequeno pedestal, então se viu que eramuito jovem. Esse movimento atraiua atenção de alguns citadinos que olhavam e até paravam para dar contribuições em dinheiro. Aos pés da "estátua",havia um cartaz, pequeno, que só pôde ser lido de muito perto, com texto explicativo sobre sua intenção de "distribuir arte pelo Brasil e retribuir às contribuições com linda mensagem". Pouco depois desta "cena" ocorrer, todos haviam desaparecido, a jovem "estátua viva” e sua família.

A combinação de religiosidade com estratégias tanto familiares, quanto engenhosas, conferem sentido específico à "arte" presente nesse caso, que incorpora o velho e o novo, tradição e criatividade, ampliando o campo que caracteriza esse espaço de consumo para além das trocas simbólicas (Bourdieu, 2008). Em sua diversidade, essas práticas, mui- 
tas vezes banais ${ }^{12}$, relacionam-se dialeticamente com a tendência a homogeneização própria da sociedade do consumo, e disputam espaço com aqueles que pretendem usar o espaço do calçadão para circulação, integrando as dinâmicas próprias das práticas espaciais, ao mesmo tempo em que conferem uma dimensão política a esse espaço público pela confrontação direta que viabilizam, assim comopela necessidade de adaptar-se frente ao outro.Não sem razão, Lipovetsky e Serroy (2010, p. 134) afirmam que a globalização não produz somente homogeneidade, mas cria igualmente heterogeneidade, diversidade e indivualidade.Segundo exemplo: num sábado de Carnaval (14/02/2015), pela manhã, o "Bloco do Guri ${ }^{13}$ " cruzou o calçadão, desde a Av. Brasil até a Praça 9 de Julho, com música e jovens fantasiados, atraindo atenção de muitos e promovendo ampla interação com frequentadores de gênero e idade variada. Mesmo que não seja diretamente compatível com a atividade comercial, a duração de cerca de 20 minutos foi bem aceita pelos vendedores que, longe de demonstrar contrariedade, pareciam satisfeitos com a transformação do calçadão em espaço de festa. O policiamento intenso que acompanhava o cortejo também chamava a atenção e parecia atender às demandas por ordem, mesmo junto a manifestações culturais bastante organizadas, como essa, cada vez mais presente nas nossas cidades, ao mesmo tempo em que se contrapõeà associação com o perigo, frequentemente feita aos espaços públicos.

Mas os jovens também estão presentes indiretamente, ou virtualmente, como potenciais consumidores, conforme evidenciam anúncios de lojas populares, como a Patibum, que menciona "a blusa da delegada da novela"14, explicitando simulacros, ao mesmo tempo em que se dirige, sobretudo às jovens e às adultas consumidoras (Figura 4).

Figura4: Presidente Prudente. Presença de homens e mulheres no calçadão. 2013

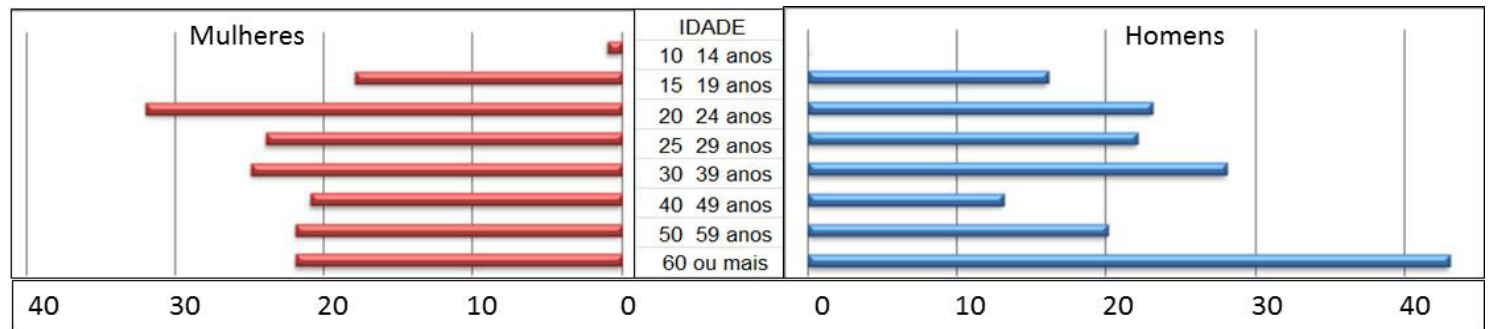

Fonte: Trabalho de campo, 2013

\footnotetext{
12 Em outros sábados, "pastores” foram vistos “pregando” no calçadão, atraindo número variável de interessados e recorrendo a estratégias mais convencionais.

13 Uma iniciativa do Projeto Guri, programa da Secretaria de Cultura do Estado de São Paulo criado em 1995, voltado à educação musical de crianças e jovens. Conta com apoio da Prefeitura Municipal e de organizações sociais, em Presidente Prudente.

${ }^{14}$ A rede de lojas busca, assim, aproveitar-se do sucesso da personagem Helô, uma delegada da telenovela Salve Jorge, exibida pela Rede Globo, em 2013. Scoralick (2010) mostra que estas narrativas ficcionais provocam identificações e projeções no telespectador, como indica o uso desta personagem efetuado pela loja Patibum Prudente Modas, situada no Calçadão.
} 
Os mesmos simulacros estão presentes nos sitesde algumas dessas lojas, como é o caso do Magazine TorraTorra que não tem vitrines, mas possui cartão de crédito próprio, atua na internet, com site, facebook e instagram. Explorando o consumo como linguagem que comunica distinções e atua de modo difuso, mas cada vez mais especializado, o site anuncia o brinco "earcuff" - "verdadeira febre entre celebridades e garotas antenadas, acessório utilizado pelas personagens das novelas" - simulando a celebrização de jovens pobres, recorrendo para isso à intertextualidade e a diferentes meios, como a TV, a internet e a loja no calçadão.

De modo semelhante, o alto volume e as músicas predominantemente estadunidenses também saem dos alto-falantes de lojas populares que são maioria no calçadão de Presidente Prudente, a partir dos anos 1990, corroborando a referida homogeneização, mas disputam com os anúncios de produtos feitos também em alto-falantes ou mesmo aos gritos por jovens vendedoras que lembram feirantes, inclusive pela oferta de produtos expostos em bancas, recriando as relações entre o velho e o novo, importantes para a caracterização desses espaços.

Mesmo que o motivo principal para a ida ao calçadão sejam as compras, tendo diminuído as práticas de lazer, elas não desapareceram e estão cotidianamente relacionadas à presença de outro sujeito, cuja importância também se evidencia com os resultados das enquetes (Figura 2) - homens idosos, que podem ser observados circulando pelo calçadão, conversando em pequenos grupos, mas, sobretudo, reunidos nas mesas sombreadas da Praça 9 de julho, em área contígua ao calçadão, jogando damas.

Em 2013, quando a praça esteve em reforma, a presença desses sujeitos foi mais intensa e visível no calçadão, disputando espaço nos novos bancos ${ }^{15}$, muitas vezes, pouco adequados à sociabilidade, em função da sua disposição e da localização, por outras dificultando a circulação, especialmente daqueles que cruzam apressadamente o calçadão, em direção ao trabalho ou aos serviços, sobretudo bancários, em função da permanência de pequenos grupos de amigos, todos homens idosos, para os quais o uso do tempo já se distanciou relativamente daquele próprio do mundo do trabalho, sem com isso conseguir se isolar das múltiplas temporalidades impostas ao espaço e nele expressas, associadas aos interesses do mercado. Quando as lojas fecham, eles também se retiram, a despeito das temperaturas mais amenas dos finais de tarde, especialmente no horário de verão.

Mas alguns retornam acompanhados das esposas para a "Noite da seresta" que acontece todo domingo, às 20 horas, no pequeno teatro de arena da praça, uma réplica modernizada dos antigos coretos (atualizando o velho e fazendo-o parecer novo), no qualse

\footnotetext{
15 A última intervenção do poder público municipal na área central de Presidente Prudente foi chamada de "revitalização", pelos
} próprios agentes responsáveis e pela mídia, e iniciou-se pelo calçadão (2011). 
apresentam músicos pouco conhecidos que, em geral, tocam estilos musicais mais tradicionais, como bolero, samba e música sertaneja. Embora o público não seja grande, o que é compatível com a pequena dimensão do próprio teatro, a baixa qualidade das atrações musicais exerce papel ambíguo ao refletir e, ao mesmo tempo, reproduzir, as características desse público. Nesse sentido, ainda que seja um investimento na manutenção de práticas espaciais de lazer e cultura nesse espaço público, feito pelo poder público municipal, nãohá aposta nas suas potencialidades de atração de outros frequentadores.

Mais uma vez, observa-se que a dialética entre o velho e o novo esteve presente, tanto na reforma do calçadão, quanto da Praça 9 de julho, e pode ser identificada, exemplarmente, na polêmica sobre o piso de pedra portuguesa, substituído no primeiro, mas mantido na segunda, por exigência do Ministério Público, frente ao qual os frequentadores demonstravam notável incompreensão, expressa em recorrentes perguntas: manter para quêe? Acrescentando que de nada adiantaria a própria reforma da praça, uma vez que as pombas, presença marcante, acabariam por expulsar outros frequentadores, inviabilizando o uso dos bancos. Os tradicionais jogadores de dominó são, inevitavelmente, os frequentadores permanentes, e o futuro é assim representado como extensão do presente inexorável ou por ele "colonizado" (Giddens, 2002, p.112).

A instalação do novo piso no calçadão foi caracterizada como adequada, porque mais moderna por alguns frequentadores, ainda que, em dias de chuva, tenha se mostrado perigosamente lisa para ostranseuntes idosos. Esses mesmos atributos foram positivamente identificados pelos jovens skatistas que se apropriam do calçadão para praticar durante o período noturno, ou seja, sem disputa com outros frequentadores. Mas sua presença é tão fugaz, quanto imprevista, embora favorecida pela nova iluminação instalada em 2011.

A despeito dos investimentos, atualmente, o que haveria de correspondente em termos de práticas espaciais associadas ao estar, ver e servistoem Presidente Prudente pode ser encontrado predominantemente nos shopping centers, sábados à noite. Mas estes centros comerciais são espaços privados de acesso coletivo, integralmente produzidos com vistas à reprodução dos capitais ali investidos, pautados no controle rígido dos frequentadores e de suas práticas, assim como da temperatura, luminosidade e umidade, representados (e vendidos) como superiores à cidade, justamente porque capazes de neutralizar imprevisibilidades (Sarlo, 2009). É com base nesses atributos que são cotidianamente praticados, o que os diferencia de espaços públicos, como o calçadão.

Em Presidente Prudente, desde os anos 1990, o centro caracteriza-se pela presença de um comércio cada vez mais popular que não se limita ao calçadão, incluindo o cha- 
mado camelódromo, e ruas adjacentes, tanto no quadrilátero central, como nas áreas pericentrais. Simultaneamente, passaram a predominar os grandes bancos (Bradesco, Santander, Banco do Brasil, Itaú etc) e as redes de lojas (Casas Bahia, Magazine Luiza, Ponto Frio, J. Mahfuz, Tanger, Lojas Pernambucanas, Torra Torra), o que demonstra a atuação dos grandes capitais ${ }^{16}$, em detrimento dos pequenos, sobretudo de origem local. Nas entrevistas que fizemos com citadinos que afirmaram frequentar o calçadão para suas compras, a menção e a essas lojas foi frequente, confirmando o papel estruturante que desempenham nas escolhas espaciais dos consumidores, orientando, deste modo, suas práticas espaciais voltadas à realização de outras atividades, visto que, frequentemente, associam a ida ao centro para a realização de várias tarefas e satisfação de múltiplas dimensões da vida.

A manutenção desse comércio deve-se, sobretudo a três fatores. Primeiro, a boa acessibilidade, seja por transporte individual, seja pelo transporte coletivo, já que o sistema viário e as linhas de ônibus ainda são predominantemente radiocêntricos ou diametrais, ou seja, passam pela área central assentada no quadrilátero já descrito, que se mantém, assim, como centro principal da cidade. Segundo, pela concentração de funções que continua a caracterizar tal área, possibilitando que inúmeras necessidades e desejos sejam atendidos, desde que não se procure por serviços e produtos exclusivos. Terceiro, pela segmentação dos espaços de consumo que caracterizam a cidade desde os anos 1980, intensificada pela ampliação da insegurança que afeta os espaços urbanos brasileiros de maneira difusa ${ }^{17}$. Nesse contexto, a reação baseada na revalorização de estereótipos generalizou-se e a histórica associação entre violência e pobreza (Misse, 2006) ganha novo vigor, influenciando, simultaneamente, tanto na tendência à evitação desses espaços centrais por parte das classes média e alta, como na justificação do emprego de mecanismos e equipamentos de controle social cada vez mais explícitos, como veremos no tópico seguinte.

A importância das relações entre a dimensão material e a dimensão simbólica reflete-senos estudos sobre o comércio que antes tendiam a se centrar na produção, com enfoques claramente econômicos (estruturas empresariais, localização etc.) e a partir dos anos1980,os estudos sobre comércio se impregnam também dos estudos culturais (Carreras, 2009). Lipevotsky e Serroy (2010, p.122) frisam a hegemonia assumida pela esfera comercial, tendo em vista que, após o capitalismo industrial, estrutura-se um capitalismo cultural que transforma setores inteiros da vida em experiências comercializadas. Isso também explica porque as pesquisas desenvolvidas desde os anos 1980 privilegiam enfo-

\footnotetext{
16 Estes localizam-se, principalmente, no calçadão, eixo principal de comércio e serviços da cidade, gerando uma divisão econômica do espaço, que se reflete numa divisão social dele, na microescala da área central, pois as demais vias da área central são menos escolhidas pelas grandes empresas.

17 Para aprofundar esta análise, tomando como referência as cidades médias, ver Sposito e Góes (2013).
} 
ques dirigidos mais ao consumo, ainda que as intrínsecas relações entre produção e consumo não sejam desconsideradas. Além disso, as mudanças no consumo, sejam de intensidade,conteúdo oustatus, conformam o mundo e a produção dos espaços urbanos, conforme se evidencia com a mudanças recentes experimentadas pelas cidades brasileiras, como Presidente Prudente, conforme discutido no tópico seguinte.

\section{CRESCIMENTO DO CONSUMO NO BRASIL: NOVAS MUDANÇAS NOCALÇADÃO}

Desde 2003, um conjunto de medidas adotadas em nível federal pelo primeiro Governo Lula (2003 - 2006), adquiriu maior visibilidade a partir de $2009^{18}$, quando economistas, sobretudo do Instituto de Pesquisa Econômica Aplicada (IPEA), anunciaram o surgimento de uma "nova classe média" (Neri, 2011), com base nos resultados obtidos em decorrência dos processos de expansão da renda interna, via políticas distributivas e aumento dos gastos públicos.

Nesse contexto, em Presidente Prudente, manteve-se a caracterização do calçadão como área de comércio popular, mas mudanças ocorreram e vem ocorrendo, ainda que seu alcance seja passível de problematização, caracterizadas em seguida, com base em cinco aspectos.

1. Reforma do calçadão (2011) com mudança do piso e do mobiliário (dispostos longitudinalmente, em sua maioria ${ }^{19}$ ), com novo projeto paisagístico e intensa iluminação no eixo central, e, além disso, as mesas das lanchonetes deixaram de ocupar o espaço público, mantendo-se nos espaços internos.

2. Reforma da Praça 9 de julho (2013), contígua ao calçadão, com manutenção do piso de pedra portuguesa, mudança do mobiliário, retirada de pontos de ônibus, instalação de wifi e contratação de empresa especializada para expulsão das pombas.

3. Inauguração recente de lojas associadas a grupos de capital suprarregional (redes ou empresas de franchising), que estavam presentes apenas nos shopping centers, como B1, Boticário, Hering e Cacau Show.

4. Ampliação do consumo de eletroeletrônicos por parte das classes populares, conforme relatado por todos os entrevistados residentes em área periférica que entrevistamos, realizada nas lojas de rede localizadas no calçadão, já mencionadas.

\footnotetext{
18 Segundo Governo Lula (2007 - 2010).

19 No calçadão, há quatro bancos protegidos, dois a dois, por caramanchões que garantem sombra e tem disposição perpendicular. Durante as observações de campo, uma mulher foi vista fazendo crochê e outra usando notebook nesses bancos.
} 
5. Mudanças no layout interno e externo de lojas de rede, como TorraTorra e Lojas Pernambucanas, sem mudança na oferta de produtos, que evidencia coerência com a "sociedade do consumo"e com processos que atingem escala global, ainda que as intensidades possam ser variadas. Tais mudanças podem estar relacionadas às reformas mencionadas acima, que teriam atuado como indutoras de iniciativas privadas. Antes reveladores da dialética entre a pujança do passado ea ameaça da obsolescência, atualmente as fachadas dessas lojas conectam-se com lojas presentes em outras cidades, da mesma rede, portanto, amplia-se a tendência a homogeneização já em curso (Figura 5).

Entretanto, uma atenção mais detida a uma dessas lojas indica outras motivações. Conforme informação disponível no site, o Magazine Torra Torra, especializado em vestuário e acessórios, mas que também vende produtos de cama, mesa e banho, surgiu em 1992, no Brás, bairro da capital paulista caracterizado pela presença de intensa e popular atividade comercial. Cresceu e chegou, em junho de 2016,a 43 lojas $^{20}$, mas "não se afastou da filosofia de origem".

No calçadão de Presidente Prudente, a loja possui dois pavimentos amplos, ligados por escada rolante, e foi reformada em 2013. Ocorreram investimentos visíveis na fachada e na decoração interna, como emprego de cores contrastantes (laranja e preto, roxo e vermelho) e de simulação de referências ao luxo (lustres reluzentes de plástico, imitando cristal, por exemplo), para "atender clientes exigentes", sem, no entanto, deixar de vender "a moda de preço baixo", e de investir em equipamentos de segurança (Figura 5). Em área central do piso térreo, demarcada apenas por vidros, um funcionário controla todo interior da loja, a partir de quatro grandes telas de computador, conectadas às câmeras de filmagem posicionadas estrategicamente. Tal mecanismo moderno, introduzido depois da reforma, combina-se com dois outros, utilizados desde antes da reforma e que não se empregam em lojas frequentadas pela classe média e a elite: um funcionário fica de frente para cada uma das duas portas (voltadas ao calçadão e a uma travessa), confrontando-se diretamente com cada consumidor que deixa a loja, além disso, as sacolas nas quais os caixas depositam as compras dos clientes são imediatamente lacradas. Por meio da presença deste funcionário, podemos avaliar a articulação intensa e contraditória entre espaço privado e público, revelando a profunda alteração do conteúdo deste em favor dos interesses das empresas, uma vez que a segurança é, no período atual e nos termos do exemplo em tela, uma mercadoria que se agrega a outras e não um direito social.

${ }^{20}$ Dentre as lojas da rede, 41 estão localizadas no Estado de São Paulo, sendo 14 na Região Metropolitana de São Paulo. As outras duas unidades estão em Recife (PE) e Londrina (PR). Fonte: http://torratorra.com.br/encontre-uma-lojal. Acesso em $11 \mathrm{de}$ julho de 2016. 
Figura 5: Presidente Prudente. Magazine Torra Torra. Arquitetura de transição no calçadão; fachada, porta principal e mecanismos de segurança. 2013

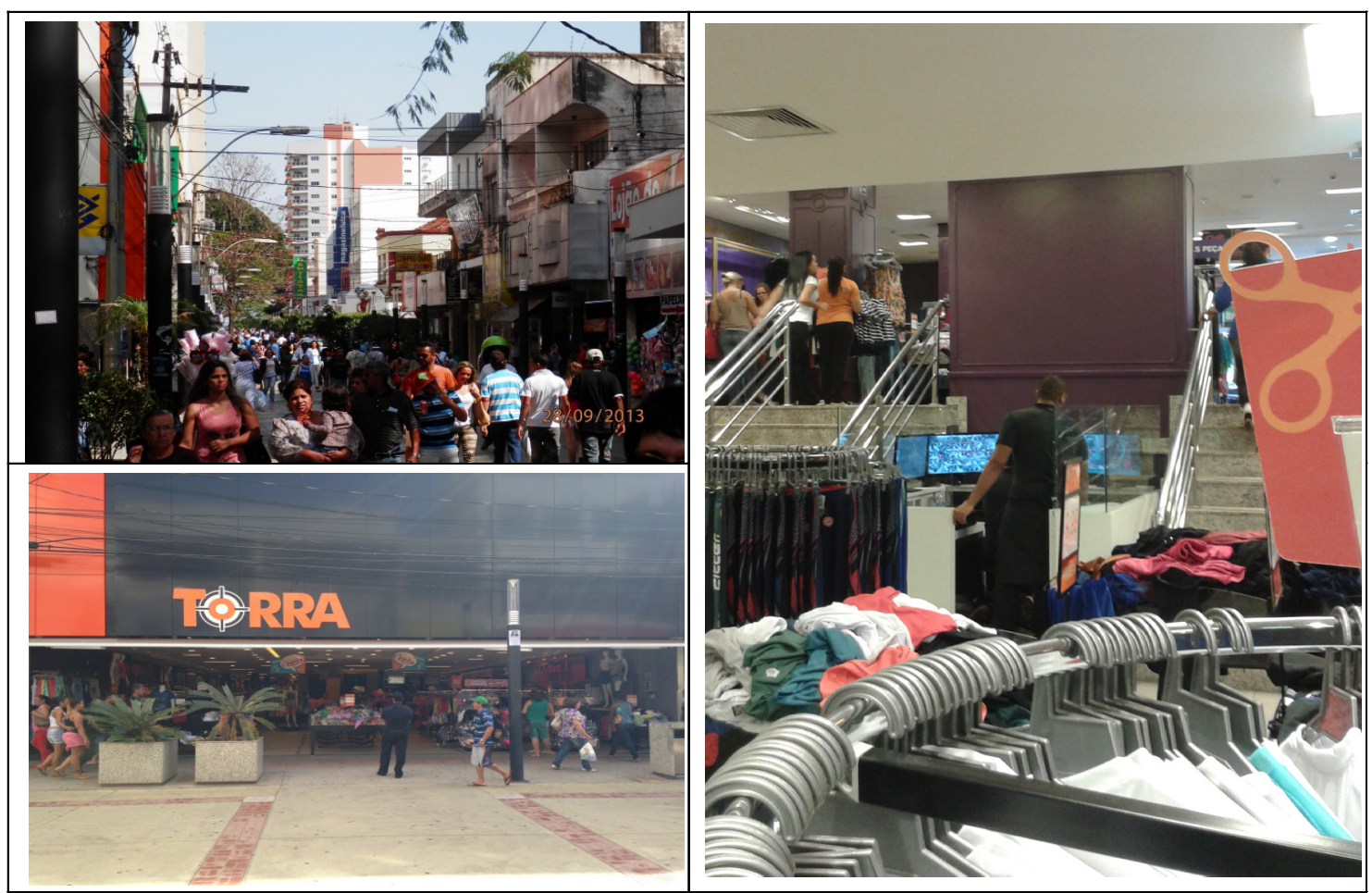

Fotos de Eda Góes, 2013.

Esses mecanismos de segurança demonstram os dilemas com os quais a loja se depara ao eleger como clientes prioritários os "pobres perigosos", convertidos simultaneamente em "clientes exigentes". Trata-se do terceiro aspecto revelador das mudanças recentemente observadas no calçadão e, simultaneamente, da identificação da outra motivação para essas reformas recentes.

Ao contrário do que se veicula pelos discursos oficiais, da mídia e mesmo de muitos economistas, esses consumidores dos "segmentos C e D" continuam a se diferenciar substancialmente das classes médias, uma vez que uma classe não se define pela renda. No entanto, podem e devem agora partilhar com as classes médias e altas "o prazer de comprar", através do qual, atendendo aos interesses do mercado e tornando ainda mais produtivo o consumo, as diferenças e privilégios historicamente reproduzidos na sociedade brasileira são, simultaneamente, amenizadas, tornadas mais suportáveis e encobertas (Souza, 2012).

Mas, como expressão da vida social, a subjetividade presente nas práticas espaciais envolve combinações contraditórias e dinâmicas entre mudança e permanência. Assim compreende-se porque, contradizendo a clientela numericamente expressiva e as inter- 
venções materiais recentes promovidas tanto por iniciativa pública, como privada, a referência à decadência do calçadão e do centro é frequente e vincula-se à representação negativa dos segmentos populares do Brasil.

Ao mesmo tempo,a dimensão espacial das estratégias de diferenciação empregadas pelas classes médias evidencia as particularidades que assume em cidades médias, nas quais, combinações de práticas espaciais diferentes podem ocorrer no âmbito de uma mesma família, quando um dos filhos "ligado em marca" e com sua própria renda, prefere comprar no shopping, enquanto outra filha, "mais humilde", considera que "isso é coisa de rico", e só faz compras no calçadão, citando o Torra Torra como uma referência (entrevista 1). Simultaneamente, um mesmo citadino pode combinar a frequência aos dois espaços, o calçadão e o shopping center, reservando ao primeiro a preferência para suas compras e ao segundo, para seu lazer (entrevista 9).

Tais combinações viabilizam-se pelas distâncias mais curtas, se comparadas às metrópoles, especialmente para quem não depende de transporte coletivo, o que tem se tornado cada vez mais frequente, inscrevendo-se tanto no processo de ampliação do acesso ao consumo (e ao crédito), quanto na busca por soluções individuais para problemas urbanos, como denota a ampliação da adoção de meios de transporte particulares ${ }^{21}$, e ainda pela influência da representação simbólica da "cidade do automóvel", como sinônimo de cidade moderna a que já fizemos referência.

A Figura 6 demonstra a predominância dos bairros populares (Vila Marcondes, Ana Jacinta, Cohab, Brasil Novo, Itapura II, Humberto Salvador...), entre os locais de residência informados pelos frequentadores em resposta às enquetes aplicadas no centro de Presidente Prudente, que foi confirmada também pelas entrevistas que fizemos com citadinos residentes em diferentes áreas da cidade. A despeito das combinações mencionadas acima, também ouvimos depoimentos de entrevistados residentes em áreas periféricas, precariamente inseridos no mercado de trabalho, com baixa renda e pouco acesso à informação e cultura. Eles explicitaram diferentes efeitos dos processos de diferenciação com expressões como "temos até vergonha de frequentar o shopping" (entrevistas 13 e 14), mas

\footnotetext{
${ }^{21}$ Em Presidente Prudente, havia, em 2005, 51.581 automóveis e 15.114 motocicletas e motonetas. Em 2015, estes números eram, respectivamente, 89.556 e 39. 011 . O incremento do número de veículos que representam, sobretudo, transporte individual e privado foi de 66.695 para 128.872 veículos, perfazendo $92,7 \%$. No mesmo período, a população cresceu, segundo as estimativas do IBGE, de 204.036 para 222.192 habitantes, o que corresponde a 8,9\% de incremento. Esta evolução denota, de um lado, uma tendência geral no território brasileiro, face à ampliação da capacidade de consumo e de acesso ao crédito, mas também uma particularidade das áreas urbanas não metropolitanas. Nestas, as distâncias menores, face aos correspondentes custos menores de combustível, possibilitam que segmentos de menor poder aquisitivo optem pelo transporte individual, acedendo, de um lado, ao modo de transporte mais prestigiado mais rápido e, de outro, resolvendo o problema da baixa mobilidade ofertada pelo transporte público, visto que a frequência dos ônibus é menor. Fontes: http://cidades.ibge.gov.br/xtras/temas.php?lang=\&cod-

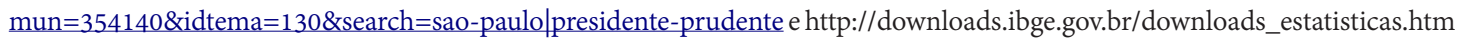


acompanhadas de comentários sobre seu desejo de vir a frequentá-lo, mesmo que fosse "só para comer uma pizza" (entrevista 13).

Figura 6: Presidente Prudente. Frequentadores do calçadão, segundo local de moradia. 2013

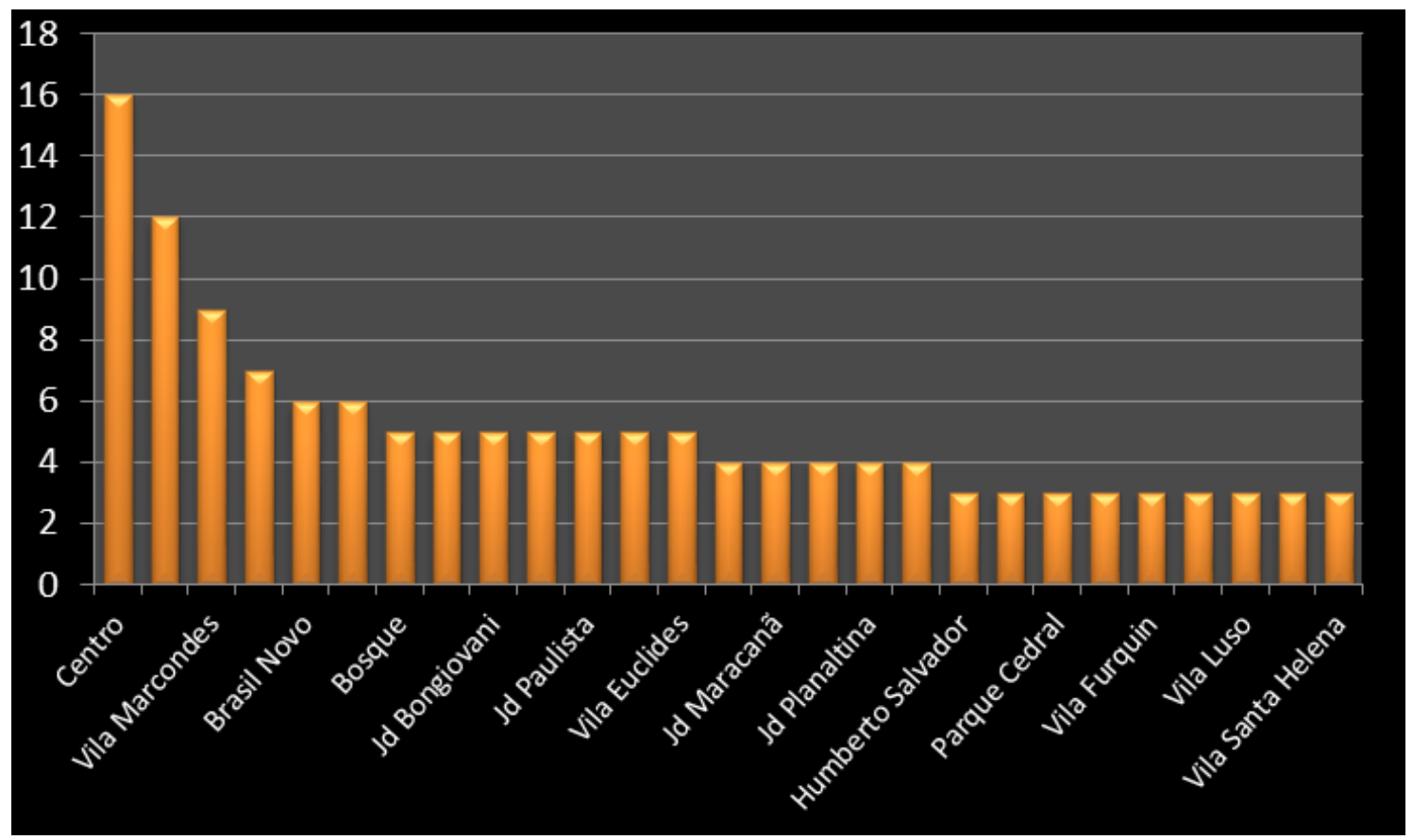

Fonte: Trabalho de campo, 2013.

\section{CONSIDERAÇÕES FINAIS}

Com base na "Geografia do cotidiano", dois sentidos principais do calçadão de Presidente Prudente foram identificados nesse artigo. Por um lado, a relação entre a desvalorização desse espaço, baseada na representação negativa de seus frequentadores, os outros, moradores de espaços periféricos e das pequenas cidades do entorno, cujas práticas de consumo se ampliaram desde 2009, mas se mantiveram "fiéis" às lojas populares de rede aí localizadas. Por outro lado, os encontros, disputas e combinações inusitadas, por vezes fugazes, de citadinos de idade e gênero diferentes, ainda que predominantemente das classes populares, com suas práticas espaciais voltadas ao comércio e aos serviços, mas que não se limitam a eles e dependem do caráter de livre acesso dos seus espaços públicos.

Ainda que as combinações entre a frequência ao calçadão e aos shopping centers sejam características específicas das cidades médias, as potencialidades dos encontros, disputas e combinações praticadas pelos diferentes sujeitos, mesmo que sejam predominan- 
temente das classes populares, fazem do calçadão e dos seus espaços contíguos, espaços praticados como públicos, porque pautados no livre acesso, na sua abertura e visibilidade, o que impossibilita que ocorram nos espaços privados, crescentemente valorizados nessa cidade, porque identificados à representação simbólica da cidade moderna. A despeito das contradições implicadas em tal identificação, são os "espaços privados de acesso e uso coletivo" dos shopping centers e das áreas de lazer exclusivas dos espaços residenciais fechados que experimentam acelerada expansão desde os anos 1990.

$\mathrm{Na}$ "cidade de muros", as relações históricas entre sociabilidade e comércio varejista precisam ser valorizadas, quando integradas aos espaços urbanos cuja abertura e acessibilidade favorecem encontros, disputas e combinações entre diferentes sujeitos, caracterizando dimensões da vida social, micropolíticas e culturais, a partir das quais, a descolonização do futuro pelo presente poderia vir a ser efetivada.

\section{REFERÊNCIAS}

1. ALONSO, Luís Enrique. La era del consumo. Madrid: Siglo XXI, 2016.

2. BAUDRILLARD, Jean. A sociedade de consumo. Lisboa: Edições 70, 1991.

3. BOURDIN, Alain. La métropole des individus. Paris: Éditions de l’Aube, 2005.

4. BOURDIEU, Pierre. A distinção. Crítica social do julgamento. São Paulo: Edusp; Porto Alegre: Zouk, 2008.

5. CALDEIRA, Teresa P.R. Cidade de muros: crime, segregação e cidadania em São Paulo. São Paulo: Edusp, 2000.

6. CANCLINI,Nestor.G. ¿Qué son los imaginarios y cómo actúan en la ciudad? EURE (Vol. XXXIII No99), Santiago de Chile, agosto de 2007, p.89-99.

7. CANCLINI, Nestor.G. Culturas Híbridas. São Paulo, EDUSP. 2013.

8. CARRERAS, Carles.; PACHECO, Suzana. (orgs.).Cidade e comércio: a rua na perspectiva internacional. São Paulo, Armazém das Letras, 2009.

9. CORTÉS, José M. G. Políticas do espaço: arquitetura, gênero e controle social. São Paulo: Senac, 2008.

10. DELGADO, Manuel. El espacio público como ideologia. Madri: Catarata, 2011.

11. GEHL, Jan. Cidades para pessoas. São Paulo: Perspectiva, 2013.

12. GIDDENS, Antohny. Modernidade e identidade. Rio de Janeiro: Zahar, 2002.

13. GOMES, Paulo C. da C. A condição urbana. Ensaios de Geopolítica da Cidade. Rio de Janeiro: Bertrand Brasil, 2002. 
14. HIRAO, Helio. Rua de pedestres: o planejamento visual urbano dos projetos públicos adequados ao contexto regional. O caso de Presidente Prudente. São Paulo: FAO/USP, 1990. (dissertação de mestrado)

15. KOHLSDORF, M. Elaine. A apreensão da forma da cidade. Brasília: Editora UNB, 1996.

16. LINDÓN, Alicia. Geografias da vida cotidiana. In: LINDÓN, Alicia; HIERNAUX, Daniel (orgs.). Tratado de Geografia Humana. Barcelona: Antrophos, 2006, p.356- 400.

17. LIPOVETSKY, Gilles, SERROY, Jean. La cultura-mundo. Respuesta a una sociedad desorientada. Barcelona: Anagrama, 2010.

18. MISSE, Michel. Crime e violência no Brasil contemporâneo. Estudos de sociologia do crime e da violência contemporânea. Rio de Janeiro: Lumen Juris, 2006.

19. NERI, Marcelo. A nova classe média. São Paulo: Saraiva, 2011.

20. SARLO, Beatriz. La ciudad vista. Buenos Aires: Siglo Veintiuno, 2009.

21. SCORALICK, Kelly. Telenovela brasileira: fascínio, projeção e identificação. Revista GEMInIS (Grupo de Estudos sobre mídias interativas em imagem e som). São Carlos: UFSCar, ano 1, n. 1,2010, p. 68 a 81 .

22. SOUZA, Jessé. Os batalhadores brasileiros. Nova classe média ou nova classe trabalhadora? Minas Gerais: Ed. UFMG, 2012.

23. SOUZA, Marcelo L. Fobópole. Rio de Janeiro: Bertrand Brasil, 2008.

24. SPOSITO, M.Encarnação B. As cidades médias e os contextos econômicos contemporâneos. In: (org). Urbanização e cidades: perspectivas geográficas. Presidente Prudente: [s.n.], 2001.

25. SPOSITO, M. EncarnaçãoB. (org.). Cidades médias: produção do espaço. São Paulo: Expressão Popular, 2007.

26. SPOSITO, M. EncarnaçãoB., GÓES, Eda M. Espaços fechados e cidades. Insegurança urbana e fragmentação socioespacial. São Paulo: Editora da UNESP, 2013.

27. VARGAS, Heliana. O Espaço Terciário. O lugar, a arquitetura e a imagem do comércio. São Paulo: SENAC, 2001.

28. WHITACKER, ArthurM. A produção do espaço urbano em Presidente Prudente: uma discussão sobre a centralidade urbana. Presidente Prudente: UNESP/FCT, 1997. (dissertação de mestrado)

Artigo recebido em 31 de julho de 2016.

Artigo aceito em 08 de agosto de 2016. 